\title{
Studi Mengenai Pengaruh Ukuran Maksimum Agregat Kasar pada Campuran Beton Memadat Mandiri (SCC)
}

\author{
FITRI YANTO HERMANSAH, ABINHOT SIHOTANG \\ Jurusan Teknik Sipil, Institut Teknologi Nasional, Bandung \\ Email: fitriyantohermansah@gmail.com
}

\begin{abstract}
ABSTRAK
Beton memadat mandiri (SCC) adalah beton inovatif yang tidak memerlukan getaran pada saat proses pelaksanaanya. Beton ini diberikan zat tambah berupa superplasticizer pada campurannya agar dapat mengalir. Berdasarkan EFNARC, beton ini harus memenuhi 3 (tiga) kriteria yaitu filling ability, passing ability dan segregation resistance. Oleh karena itu dilakukan penelitian untuk mengetahui sifat beton segar dan beton keras pada campuran beton SCC dengan ukuran agregat kasar maksimum $10 \mathrm{~mm}$ dan $20 \mathrm{~mm}$. Kemudian komposisi campuran juga dibedakan berdasarkan modulus kehalusan gabungan agregat yang seragam dan bervariasi. Kuat tekan target pada campuran beton SCC 27 MPa dan 47 MPa.Perancangan campuran beton SCC untuk penelitian ini menggunakan cara SNI yang dimodifikasi dengan metode Dreux. Kadar superplasticizer yang digunakan untuk semua jenis campuran sebesar 1,5\% dari berat semen. Hasil pengujian beton SCC menunjukan campuran mempunyai karakteristik yang relatif seragam jika modulus kehalusan agregat campuran mempunyai nilai yang sama.
\end{abstract}

Kata kunci: beton memadat mandiri (SCC), modulus kehalusan, ukuran maksimum agregat, superplasticizer.

\begin{abstract}
Self Compacting Concrete (SCC) is an innovative concrete that doesn't require vibration during the process. This concrete is added with a superplasticizer in the mixture. Based on EFNARC, this concrete must fulfill 3 (three) conditions, such asfilling ability, passing ability and segregation resistance. Therefore, a study was conducted to determine the characteristic of fresh concrete and hard concrete in SCC mixtures with maximum size of $10-\mathrm{mm}$ and $20-\mathrm{mm}$ coarse agregates. The target compressive strength of SCC mixturesis $27 \mathrm{MPa}$ and $47 \mathrm{MPa}$. In this study, the design of the SCC mixtures uses the SNI method that modified by the Dreux Method. The superplasticizer content used for all types of SCC mixtures is $1.5 \%$ of the weight of cement. The SCC test result shows the mixtures have relatively uniform characteristics if the fineness modulus of aggregate has the same value.
\end{abstract}

Keywords: self-compacting concrete (SCC), fineness modulus, maximum agregate size, superplasticizer 


\section{PENDAHULUAN}

Perkembangan teknologi beton dalam bidang konstruksi berkembang cukup pesat, baik dari segi material maupun metode pelaksanaannya. Beton memadat mandiri (SCC) adalah beton yang dapat dicetak pada bekisting dengan sendirinya mengalir tanpa harus menggunakan alat pemadat pada saat proses pengerjaanya. Saat proses pengecoran beton SCC, beton ini mengalir dan masih rentan terhadap segregasi atau pemisahan agregat kasar dengan mortar yang disebabkan oleh aliran mortar yang cepat sehingga berpisah dari agregat kasar. Jika ukuran agregat maksimum agregat kasar diperkecil sehingga tidak berbeda ekstrim dengan ukuran maksimum agregat halus, diduga segregasi tidak akan terjadi sekalipun jumlah agregat halus tidak diperbanyak melebihi jumlah agregat kasar. Berdasarkan dugaan ini nampaknya kinerja sifat fisik campuran beton segar SCC (filling ability, passing ability dan segregation resistance) dipengaruhi oleh ukuran maksimum agregat kasar yang digunakan. Permasalahan yang akan dibahas dalam penelitian ini adalah campuran beton SCC rentan terhadap ketidakhomogenan dan homogenitas campuran beton SCC diduga dipengaruhi oleh ukuran maksimum agregat kasar yang digunakan.

Lingkup penelitian yang dilakukan dalam penelitian ini adalah sebagai berikut:

1. Campuran beton SCC diaplikasikan dengan kuat tekan silinder beton $\left(f^{\prime} c\right)$ umur 28 hari 27 $\mathrm{MPa}$ dan $47 \mathrm{MPa}$.

2. Agregat kasar yang digunakan adalah batu pecah dengan ukuran maksimum $10 \mathrm{~mm}, 20$ $\mathrm{mm}$, dan $40 \mathrm{~mm}$.

3. Jenis pasir yang digunakan adalah Pasir Cimalaka.

4. Semen yang digunakan adalah Semen Portland Pozzolan Cement (PPC) Tiga Roda.

5. Superplasticizer yang digunakan adalah Sika Visconcrete $3115 \mathrm{~N}$.

6. Pengujian yang dilakukan adalah uji tekan umur 7 hari dan 28 hari, uji slumpflow, uji $V$-funnel, dan uji L-box.

\section{TINJAUAN PUSTAKA}

\subsection{Beton Memadat Mandiri (SCC)}

Secara umum komposisi beton SCC dapat dilihat pada Gambar 1 berikut:

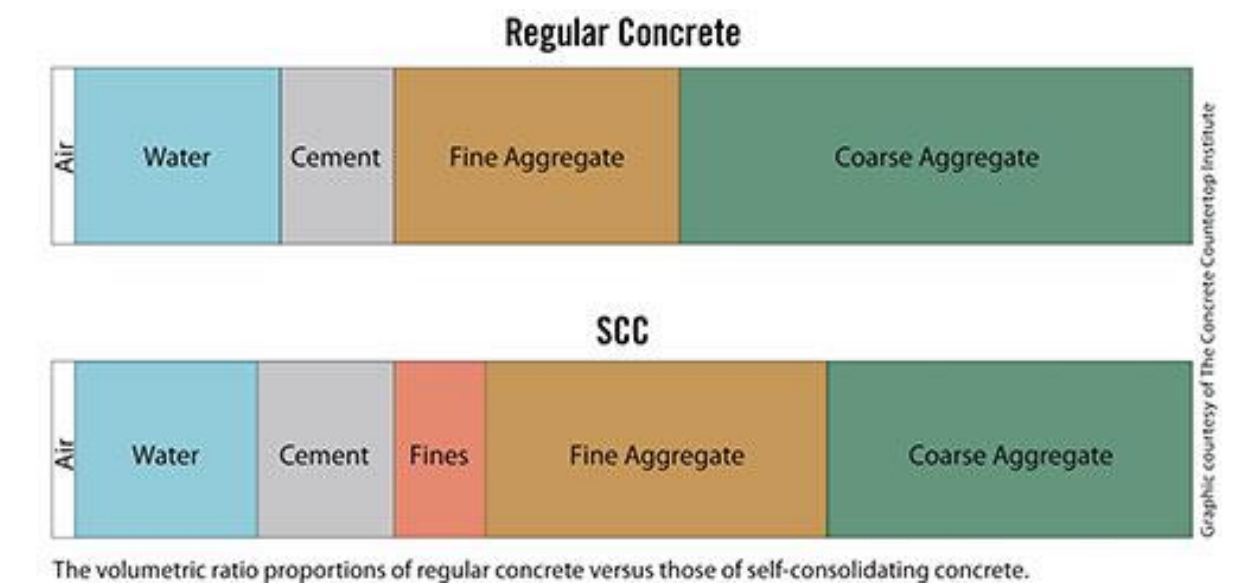

\section{Gambar 1. Perbandingan komposisi beton konvensional dan beton SCC (sumber:https://www.concretedecor.net)}

Beton SCC dikembangkan untuk mempermudah pengerjaan pengecoran pada elemen struktur yang memiliki tulangan yang rapat, sehingga beton SCC harus memenuhi 3 (tiga) kriteria yaitu mampu mengalir, melewati celah, dan mecegah terjadi segregasi. Berikut kriteria beton SCC menurut EFNARC dapat dilihat pada Tabel $\mathbf{1}$. 
Tabel 1. Kriteria Beton SCC

\begin{tabular}{|c|c|c|}
\hline Class & Slump-flow in, [mm] & \\
\hline SF 1 & 550 to 650 & \\
\hline SF 2 & 660 to 750 & \\
\hline \multirow[t]{2}{*}{ SF 3} & 760 to 850 & \\
\hline & $T_{500,}[\mathrm{~s}]$ & V-funnel time, [s] \\
\hline VS1/VF1 & $\leq 2$ & $\leq 8$ \\
\hline \multirow[t]{2}{*}{ VS2/VF2 } & $>2$ & 9 to 25 \\
\hline & Passing ability & \\
\hline PA1 & $\geq 0,80$ with 2 rebars & \\
\hline \multirow[t]{2}{*}{ PA2 } & $\geq 0,80$ with 3 rebars & \\
\hline & gregation Resistance, [\%] & \\
\hline SR1 & $\leq 20$ & \\
\hline SR2 & $\leq 15$ & \\
\hline
\end{tabular}

(sumber: EFNARC, 2005)

\subsection{Perancangan Campuran Beton SCC}

Perancangan campuran beton memadat mandiri (SCC) telah dilakukan oleh banyak peneliti, diantaranya Aggarwal dan rekan (2008), Abdizadeh dan rekan (2009), Abdelgader dan rekan (2014), dan Kumar dan rekan (2018). Selain dari beberapa penelitian yang telah dilakukan, EFNARC dan ACI telah mengeluarkan komposisi campuran beton SCC. Berikut merupakan komposisi perancangan campuran beton SCC, hasil karakteristik beton SCC dan kuat tekan prediksi pada campuran Abdelgader dan rekan seperti yang disajikan pada Tabel 2, Tabel 3 dan Tabel 4.

Tabel 2. Komposisi Campuran Beton SCC

\begin{tabular}{ccccc}
\hline Uraian & $\mathbf{1}$ & $\mathbf{2}$ & $\mathbf{3}$ & $\mathbf{4}$ \\
\hline Faktor air-semen & 0,375 & 0,400 & 0,425 & 0,450 \\
Semen $\left[\mathbf{k g} / \mathbf{m}^{\mathbf{3}}\right]$ & 450 & 450 & 450 & 450 \\
Air $\left[\mathbf{k g} / \mathbf{m}^{\mathbf{3}}\right]$ & 168,8 & 180 & 191 & 202,5 \\
Batu pecah $\left[\mathbf{k g} / \mathbf{m}^{\mathbf{3}}\right]$ & 918 & 903 & 888 & 873 \\
Pasir $\left[\mathbf{k g} / \mathbf{m}^{\mathbf{3}}\right]$ & 918 & 903 & 888 & 873 \\
Superplasticizer $[\%]$ & 1,8 & 1,5 & 0,8 & 0,8 \\
\hline
\end{tabular}

(Sumber: Abdelgader dan rekan, 2014) 
Tabel 3. Hasil Pengujian Karakteristik Beton SCC

\begin{tabular}{lcccc}
\hline \multicolumn{1}{c}{ Uraian } & $\mathbf{1}$ & $\mathbf{2}$ & $\mathbf{3}$ & $\mathbf{4}$ \\
\hline Slum flow $[\mathbf{m m}$ ] & 730 & 730 & 760 & 770 \\
$\boldsymbol{T}_{\mathbf{5 0 0}}$ [sec] & 3,7 & 3,4 & 1,2 & 1 \\
$\boldsymbol{V}$-funne/ [sec] & 10 & 6 & 6,9 & 5 \\
L-Box ratio & 0,89 & 0,89 & 0,91 & 0,81 \\
Bleeding & Med & Med & Non & Non \\
28-days [MPa] & 43 & 39 & 40,5 & 41 \\
\hline (Sumber: Abdelgader dan rekan,2014)
\end{tabular}

Tabel 4. Prediksi Kuat Tekan Beton SCC Abdelgader dan Rekan

\begin{tabular}{cccccccc}
\hline No & $\begin{array}{c}\text { Semen } \\
{\left[\mathbf{k g} / \mathbf{m}^{\mathbf{3}}\right]}\end{array}$ & $\begin{array}{c}\text { Agregat halus } \\
{\left[\mathbf{k g} / \mathbf{m}^{\mathbf{3}}\right]}\end{array}$ & $\begin{array}{c}\text { Agregat Kasar } \\
{\left[\mathbf{k g} / \mathbf{m}^{\mathbf{3}}\right]}\end{array}$ & $\begin{array}{c}\text { Air } \\
{\left[\mathbf{k g} / \mathbf{m}^{\mathbf{3}}\right]}\end{array}$ & $\begin{array}{c}\text { Superplasticizer } \\
{[\%]}\end{array}$ & $\begin{array}{c}\boldsymbol{f}_{\boldsymbol{c}}^{\prime} \text { Prediksi } \\
{[\mathbf{M P a}]}\end{array}$ & $\begin{array}{c}\boldsymbol{f}_{\boldsymbol{c}}^{\prime} \text { Aktual } \\
{[\mathbf{M P a}]}\end{array}$ \\
\hline $\mathbf{1}$ & 450 & 918 & 918 & 168,8 & 1,8 & 46,241 & 43 \\
$\mathbf{2}$ & 450 & 903 & 903 & 180 & 1,5 & 42,7 & 39 \\
$\mathbf{3}$ & 450 & 888 & 888 & 191 & 0,5 & 39,626 & 40,5 \\
\hline
\end{tabular}

Berdasarkan komposisi campuran SCC yang tertera pada Tabel $\mathbf{2}$ dapat disimpulkan bahwa jumlah agregat halus lebih banyak daripada jumlah agregat kasar. Jumlah agregat halus lebih banyak daripada jumlah agregat kasar ditujukan untuk terjadinya aliran campuran beton yang membawa agregat kasar sehingga tidak terjadi segregasi. Kemudian kuat tekan beton didapat dari faktor air-semen campuran beton. Hal ini menunjukan campuran beton SCC dapat direncanakan dengan menggunakan acuan SNI 2843-2000 mengenai tata cara pembuatan campuran beton normal. Kemudian hasil perancangan tersebut dikembangkan menggunakan Metode Dreux untuk mendekati konsep Okamura.

\subsection{Pengaruh Gradasi Agregat Kasar Terhadap Kinerja Sifat Fisik Campuran Beton Self Compacting Concrete (SCC)}

Berdasarkan SNI 2843-2000 ukuran maksimum agregat kasar yang cocok untuk campuran beton SCC adalah $10 \mathrm{~mm}$. Hal ini diperoleh dari kadar agregat halus pada campuran beton melebihi $50 \%$ dari jumlah total agregat gabungan. Namun untuk ukuran maksimum agregat $20 \mathrm{~mm}$ dan $40 \mathrm{~mm}$ maka gradasi agregat harus dikoreksi terlebih dahulu, sehingga nilai modulus kehalusan gabungan agregat atau specific surface mempunyai nilai yang sama serta campuran beton dengan ukuran agregat kasar $20 \mathrm{~mm}$ dan $40 \mathrm{~mm}$ mempunyai persen pasir lebih dari $50 \%$ dari jumlah total agregat gabungan, sehingga kelecakan (workability) campuran dapat terjaga dan jumlah pasir lebih banyak dibandingkan jumlah agregat kasar, seperti pada Tabel 5. 
Tabel 5.Campuran Beton dengan Modulus Kehalusan Agregat Gabungan Seragam

\begin{tabular}{cccccc}
\hline \multirow{2}{*}{$\begin{array}{c}\text { Ukuran saringan } \\
\text { [mm] }\end{array}$} & $\begin{array}{c}\text { Gradasi } \\
\text { acuan } \\
{[\%]}\end{array}$ & \multicolumn{5}{c}{ Gradasi Aktual [\%] } \\
\cline { 5 - 6 } $20-10$ & 56,5 & 58 & 61,5 & 62 & 65 \\
$10-5$ & 5,5 & - & - & - & - \\
$5-2.5$ & 5 & 9 & - & - & - \\
$2.5-1.2$ & 7 & 8 & 10 & - & - \\
$1.2-0.6$ & 6 & 7 & 9 & 18 & - \\
$0.6-0.3$ & 6,5 & 6,5 & 7,5 & 12 & 29 \\
$0.3-0.15$ & 6,5 & 6 & 6.5 & 7 & 6 \\
$<0.15$ & 7 & 5,5 & 5,5 & 1 & - \\
Modulus kehalusan & 5,19 & 5,19 & 5,19 & 5,19 & 5,19 \\
c/w & 2,00 & 2,00 & 2,00 & 2,00 & 2,00 \\
s/ump rencana & 40 & 40 & 40 & 40 & 40 \\
slump aktual & 35 & 35 & 35 & 40 & 40 \\
Kuat tekan rencana & 30 & 30 & 30 & 30 & 30 \\
{$[$ MPa], 28 hari } & & & & & \\
Kuat tekan aktual & 35,35 & 35,35 & 40,127 & 36,306 & 36,943 \\
[MPa], 33 hari & & & & &
\end{tabular}

(Sumber: Saelan, P dan Arifin, Z., 2002)

\section{METODE PENELITIAN}

Parameter untuk penelitian ini meliputi slumpflow, waktu aliran $T_{500}$, waktu aliran $V$-funnel, blocking ratio $(\mathrm{H} 2 / \mathrm{H} 1)$ dan kuat tekan beton. Selanjutnya variabel penelitian yaitu ukuran agregat kasar $10 \mathrm{~mm}$ dan $20 \mathrm{~mm}$. Pengujian yang dilakukan pada beton segar dan beton keras. Kemudian dilakukan analisis dan pembahasan hasil penelitian dan terakhir kesimpulan dan saran dari hasil penelitian yang terkait.

\section{ANALISIS DAN PEMBAHASAN}

\subsection{Perancangan Campuran Beton SCC}

Berikut ini merupakan hasil perancangan campuran beton SCC untuk kuat tekan target 27,38 MPa dengan modulus kehalusan gabungan seragam dan bervariasi. Hasil perancangan ini telah dimodifikasi dengan Metode Dreux seperti pada Tabel 6 dan Tabel 7. 
Tabel 6. Campuran Beton SCC Modulus Kehalusan Seragam dan Kuat Tekan Target 27,38 MPa

\begin{tabular}{|c|c|c|c|c|c|c|c|c|c|c|}
\hline \multirow{2}{*}{ Uraian } & \multicolumn{2}{|c|}{ FM 1} & \multicolumn{2}{|c|}{ FM 2} & \multicolumn{2}{|c|}{ FM 3} & \multicolumn{2}{|c|}{ FM 4} & \multicolumn{2}{|c|}{ FM 5} \\
\hline & $\mathbf{F M}$ & Persen & $\mathbf{F M}$ & Persen & FM & Persen & $\mathbf{F M}$ & Persen & $\mathbf{F M}$ & Persen \\
\hline Agregat Kasar & 5,41 & 43 & 5,77 & 38,12 & 6,14 & 36,7 & 6,50 & 34,2 & 6,86 & 31,4 \\
\hline Pasir & 2,93 & 57 & 2,93 & 61,88 & 2,93 & 63,3 & 2,93 & 65,8 & 2,93 & 68,6 \\
\hline Modulus kehalusan gabungan & \multicolumn{2}{|r|}{4,00} & \multicolumn{2}{|c|}{4,00} & \multicolumn{2}{|c|}{4,00} & \multicolumn{2}{|c|}{4,00} & \multicolumn{2}{|c|}{4,00} \\
\hline Agregat Kasar $20 \mathrm{~mm}\left[\mathrm{~kg} / \mathrm{m}^{3}\right]$ & \multicolumn{2}{|r|}{-} & \multicolumn{2}{|c|}{143,34} & \multicolumn{2}{|c|}{276,19} & \multicolumn{2}{|c|}{338,32} & \multicolumn{2}{|c|}{472,61} \\
\hline Agregat Kasar 10 mm $\left[\mathrm{kg} / \mathrm{m}^{3}\right]$ & \multicolumn{2}{|c|}{681,0} & \multicolumn{2}{|c|}{430,03} & \multicolumn{2}{|c|}{276,19} & \multicolumn{2}{|c|}{129,44} & \multicolumn{2}{|r|}{-} \\
\hline Pasir $\left[\mathbf{k g} / \mathbf{m}^{3}\right]$ & \multicolumn{2}{|c|}{918,5} & \multicolumn{2}{|c|}{931,38} & \multicolumn{2}{|c|}{952,75} & \multicolumn{2}{|c|}{990,38} & \multicolumn{2}{|c|}{$1.032,52$} \\
\hline Semen $\left[\mathbf{k g} / \mathbf{m}^{3}\right]$ & \multicolumn{2}{|r|}{382} & \multicolumn{2}{|c|}{350} & \multicolumn{2}{|c|}{350} & \multicolumn{2}{|c|}{350} & \multicolumn{2}{|c|}{350} \\
\hline $\operatorname{Air}\left[\mathbf{k g} / \mathbf{m}^{3}\right]$ & \multicolumn{2}{|r|}{229} & \multicolumn{2}{|c|}{210} & \multicolumn{2}{|c|}{210} & \multicolumn{2}{|c|}{210} & \multicolumn{2}{|c|}{210} \\
\hline Superplasticizer [\%] & \multicolumn{2}{|r|}{1,5} & \multicolumn{2}{|c|}{1,5} & & 1,5 & & 1,5 & & 1,5 \\
\hline
\end{tabular}

Tabel 7. Campuran beton SCC Modulus Kehalusan Bervariasi dan Kuat Tekan Target 27,38 MPa

\begin{tabular}{|c|c|c|c|c|c|c|c|c|c|c|}
\hline \multirow{2}{*}{ Uraian } & \multicolumn{2}{|c|}{ TM1 } & \multicolumn{2}{|c|}{ TM 2} & \multicolumn{2}{|c|}{ TM 3} & \multicolumn{2}{|c|}{ TM 4} & \multicolumn{2}{|c|}{ TM 5} \\
\hline & $\mathbf{F M}$ & Persen & FM & Persen & FM & Persen & $\mathbf{F M}$ & Persen & $\mathbf{F M}$ & Persen \\
\hline Agregat Kasar & 5,41 & 43 & 5,78 & 46 & 6,14 & 46 & 6,50 & 46 & 6,86 & 46 \\
\hline Pasir & 2,93 & 57 & 2,93 & 54 & 2,93 & 54 & 2,93 & 54 & 2,93 & 54 \\
\hline Modulus kehalusan gabungan & \multicolumn{2}{|c|}{4,00} & \multicolumn{2}{|c|}{4,24} & \multicolumn{2}{|c|}{4,41} & \multicolumn{2}{|c|}{4,57} & \multicolumn{2}{|c|}{4,74} \\
\hline Agregat Kasar $20 \mathrm{~mm}\left[\mathrm{~kg} / \mathrm{m}^{3}\right]$ & \multicolumn{2}{|r|}{-} & \multicolumn{2}{|c|}{188,35} & \multicolumn{2}{|c|}{376,71} & \multicolumn{2}{|c|}{565,06} & \multicolumn{2}{|c|}{753,42} \\
\hline Agregat Kasar $10 \mathrm{~mm}\left[\mathrm{~kg} / \mathrm{m}^{3}\right]$ & \multicolumn{2}{|c|}{681} & \multicolumn{2}{|c|}{565,06} & \multicolumn{2}{|c|}{376,71} & \multicolumn{2}{|c|}{188,35} & \multicolumn{2}{|r|}{ 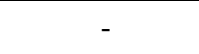 } \\
\hline Pasir $\left[\mathrm{kg} / \mathrm{m}^{3}\right]$ & \multicolumn{2}{|c|}{918,5} & \multicolumn{2}{|c|}{918,5} & \multicolumn{2}{|c|}{918,5} & \multicolumn{2}{|c|}{918,5} & \multicolumn{2}{|c|}{918,5} \\
\hline Semen $\left[\mathrm{kg} / \mathrm{m}^{3}\right]$ & \multicolumn{2}{|c|}{382} & \multicolumn{2}{|c|}{350} & \multicolumn{2}{|c|}{350} & \multicolumn{2}{|c|}{350} & \multicolumn{2}{|c|}{350} \\
\hline Air $\left[\mathrm{kg} / \mathrm{m}^{3}\right]$ & \multicolumn{2}{|r|}{229} & \multicolumn{2}{|c|}{210} & \multicolumn{2}{|c|}{210} & \multicolumn{2}{|c|}{210} & \multicolumn{2}{|r|}{210} \\
\hline Superplasticizer [\%] & \multicolumn{2}{|r|}{1,5} & \multicolumn{2}{|c|}{1,5} & & 1,5 & & 1,5 & & 1,5 \\
\hline
\end{tabular}

Selanjutnya merupakan komposisi campuran beton SCC dengan kuat tekan target 47,38 MPa dengan modulus kehalusan agregat gabungan seragam dan bervariasi. Hasil komposisi ini juga telah dimodifikasi dengan Metode Dreux. Seperti pada Tabel 8 dan Tabel 9.

Tabel 8. Campuran Beton SCC Modulus Kehalusan Seragam dan Kuat Tekan Target 47,38 MPa

\begin{tabular}{|c|c|c|c|c|c|c|c|c|c|c|}
\hline \multirow{2}{*}{ Uraian } & \multicolumn{2}{|c|}{ FM 1} & \multicolumn{2}{|c|}{ FM 2} & \multicolumn{2}{|c|}{ FM 3} & \multicolumn{2}{|c|}{ FM 4} & \multicolumn{2}{|c|}{ FM 5} \\
\hline & $\mathbf{F M}$ & Persen & $\mathbf{F M}$ & Persen & $\mathbf{F M}$ & Persen & $\mathbf{F M}$ & Persen & $\mathbf{F M}$ & Persen \\
\hline Agregat Kasar & 5,41 & 35 & 5,78 & 32.38 & 6,14 & 28,46 & 6,50 & 25,38 & 6,86 & 22,91 \\
\hline Pasir & 2,93 & 65 & 2,93 & 67.62 & 2,93 & 71,54 & 2,93 & 74,62 & 2,93 & 77,09 \\
\hline Modulus kehalusan gabungan & \multicolumn{2}{|c|}{4,00} & \multicolumn{2}{|c|}{4,00} & \multicolumn{2}{|c|}{4,00} & \multicolumn{2}{|c|}{4,00} & \multicolumn{2}{|c|}{4,00} \\
\hline Agregat Kasar $20 \mathrm{~mm}\left[\mathrm{~kg} / \mathrm{m}^{3}\right]$ & \multicolumn{2}{|r|}{-} & \multicolumn{2}{|c|}{123,75} & \multicolumn{2}{|c|}{217,54} & \multicolumn{2}{|c|}{291,00} & \multicolumn{2}{|c|}{350,23} \\
\hline Agregat Kasar $10 \mathrm{~mm}\left[\mathrm{~kg} / \mathrm{m}^{3}\right]$ & \multicolumn{2}{|c|}{517,01} & \multicolumn{2}{|c|}{371,25} & \multicolumn{2}{|c|}{217,54} & \multicolumn{2}{|c|}{97,00} & \multicolumn{2}{|r|}{-} \\
\hline Pasir $\left[\mathrm{kg} / \mathbf{m}^{3}\right]$ & \multicolumn{2}{|c|}{926,02} & \multicolumn{2}{|c|}{$1.033,73$} & \multicolumn{2}{|c|}{$1.093,65$} & \multicolumn{2}{|c|}{$1.140,74$} & \multicolumn{2}{|c|}{1.178 .50} \\
\hline Semen $\left[\mathrm{kg} / \mathrm{m}^{3}\right]$ & \multicolumn{2}{|c|}{509} & \multicolumn{2}{|c|}{525} & \multicolumn{2}{|c|}{525} & \multicolumn{2}{|c|}{525} & \multicolumn{2}{|c|}{525} \\
\hline Air $\left[\mathrm{kg} / \mathbf{m}^{3}\right]$ & \multicolumn{2}{|c|}{229} & \multicolumn{2}{|c|}{210} & \multicolumn{2}{|c|}{210} & \multicolumn{2}{|c|}{210} & \multicolumn{2}{|c|}{210} \\
\hline Superplasticizer [\%] & \multicolumn{2}{|c|}{1.5} & \multicolumn{2}{|c|}{1.5} & & 1.5 & & 1.5 & & 1.5 \\
\hline
\end{tabular}


Tabel 9. Campuran Beton SCC Modulus Kehalusan Bervariasi dan Kuat Tekan Target 47,38 MPa

\begin{tabular}{|c|c|c|c|c|c|c|c|c|c|c|}
\hline \multirow{2}{*}{ Uraian } & \multicolumn{2}{|c|}{ TM1 } & \multicolumn{2}{|c|}{ TM 2} & \multicolumn{2}{|c|}{ TM 3} & \multicolumn{2}{|c|}{ TM 4} & \multicolumn{2}{|c|}{ TM 5} \\
\hline & $\mathbf{F M}$ & Persen & $\mathbf{F M}$ & Persen & $\mathbf{F M}$ & Persen & $\mathbf{F M}$ & Persen & $\mathbf{F M}$ & Persen \\
\hline Agregat Kasar & 5,41 & 35 & 5,78 & 38,5 & 6,14 & 38,5 & 6,50 & 38,5 & 6,86 & 38,5 \\
\hline Pasir & 2,93 & 65 & 2,93 & 61,5 & 2,93 & 61,5 & 2,93 & 61,5 & 2,93 & 61,5 \\
\hline Modulus kehalusan gabungan & \multicolumn{2}{|c|}{4,00} & \multicolumn{2}{|c|}{4,24} & \multicolumn{2}{|c|}{4,40} & \multicolumn{2}{|c|}{4,57} & \multicolumn{2}{|r|}{4,74} \\
\hline Agregat Kasar $20 \mathrm{~mm}\left[\mathrm{~kg} / \mathrm{m}^{3}\right]$ & \multicolumn{2}{|r|}{-} & \multicolumn{2}{|c|}{150,68} & \multicolumn{2}{|c|}{301,37} & \multicolumn{2}{|c|}{452,05} & \multicolumn{2}{|c|}{602,73} \\
\hline Agregat Kasar $10 \mathrm{~mm}\left[\mathrm{~kg} / \mathrm{m}^{3}\right]$ & \multicolumn{2}{|c|}{517,01} & \multicolumn{2}{|c|}{452,05} & \multicolumn{2}{|c|}{301,37} & \multicolumn{2}{|c|}{150,68} & \multicolumn{2}{|r|}{-} \\
\hline Pasir $\left[\mathbf{k g} / \mathbf{m}^{3}\right]$ & \multicolumn{2}{|c|}{926,02} & \multicolumn{2}{|c|}{926,02} & \multicolumn{2}{|c|}{926,02} & \multicolumn{2}{|c|}{926,02} & \multicolumn{2}{|c|}{926,02} \\
\hline Semen $\left[\mathbf{k g} / \mathbf{m}^{3}\right]$ & \multicolumn{2}{|c|}{509} & \multicolumn{2}{|c|}{525} & \multicolumn{2}{|c|}{525} & \multicolumn{2}{|c|}{525} & \multicolumn{2}{|r|}{525} \\
\hline Air $\left[\mathrm{kg} / \mathrm{m}^{3}\right]$ & \multicolumn{2}{|c|}{229} & \multicolumn{2}{|c|}{210} & \multicolumn{2}{|c|}{210} & \multicolumn{2}{|r|}{210} & \multicolumn{2}{|r|}{210} \\
\hline Superplasticizer [\%] & \multicolumn{2}{|r|}{1,5} & \multicolumn{2}{|c|}{1,5} & & 1,5 & & 1,5 & & 1,5 \\
\hline
\end{tabular}

Penggunaan superplasticizer pada penelitian ini dilakukan secara coba-coba (trial) yang diawali dengan $0,5 \% ; 1 \%$ dan $1,5 \%$ terhadap berat semen. Sehingga diperoleh kadar superplasticizer yang digunakan $1,5 \%$ untuk setiap campuran.

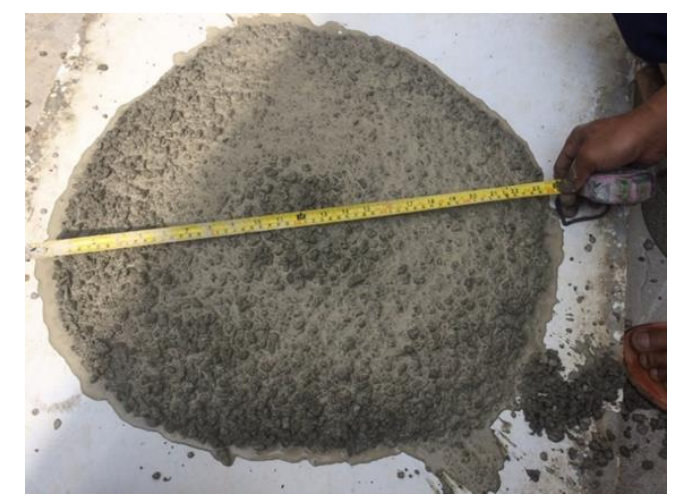

Gambar 2. Slumpflow dengan kadar superplasticizer 1.5\%

\subsection{Hasil Pengujian Beton SCC}

Berikut ini merupakan hasil pengujian untuk beton SCC kuat tekan target 27,38 MPa dengan modulus kehalusan seragam dan bervariasi, disajikan pada Tabel 10 dan Tabel 11.

Tabel 10. Hasil Pengujian Beton SCC Kuat Tekan 27,38 MPa Modulus Kehalusan Seragam

\begin{tabular}{lccccc}
\hline \multicolumn{1}{c}{ Uraian } & TM1 & TM2 & TM3 & TM4 & TM5 \\
\hline Modulus Kehalusan Gabungan & 4,00 & 4,24 & 4,41 & 4,57 & 4,74 \\
\hline Slumpflow [mm] & 650 & 620 & 630 & 610 & 600 \\
\hline $\boldsymbol{T}_{\mathbf{5 0 0},[\mathbf{s e c} \text { ] }}$ & 4 & 5 & 5 & 4 & 5 \\
\hline V-funnel [sec] & 9 & 12 & 13 & 14 & 18 \\
\hline L-Box ratio & 0,05 & 0,08 & 0,05 & 0,11 & 0,05 \\
\hline Kuat tekan 7 hari [MPa] & 19,87 & 18,09 & 18,25 & 18,66 & 19,11 \\
\hline Kuat tekan 28 hari [MPa] & 29,1 & 29,4 & 29,4 & 28,8 & 29,8 \\
\hline
\end{tabular}


Tabel 11. Hasil Pengujian Beton SCC Kuat Tekan 27,38 MPa Modulus Kehalusan Bervariasi

\begin{tabular}{cccccc}
\hline Uraian & FM1 & FM2 & FM3 & FM4 & FM5 \\
\hline Modulus Kehalusan Gabungan & 4,00 & 4,00 & 4,00 & 4,00 & 4,00 \\
\hline Slumpflow $[\mathbf{m m}$ ] & 635 & 630 & 640 & 640 & 630 \\
\hline $\boldsymbol{T}_{\text {500, }}$ [sec] & 4 & 5 & 4 & 4 & 5 \\
\hline V-funnel [sec] & 11 & 10 & 11 & 11 & 10 \\
\hline L Box [H2/H1] & 0,41 & 0,45 & 0,42 & 0,43 & 0,44 \\
\hline Kuat tekan 7 hari [MPa] & 18,32 & 19,31 & 18,85 & 17,92 & 17,12 \\
\hline Kuat tekan 28 hari [MPa] & 28,6 & 28,9 & 28,7 & 27,8 & 27,1 \\
\hline
\end{tabular}

Dari hasil pengujian tersebut diperoleh, jika modulus kehalusan agregat gabungan yang mempengaruhi kelecakan campuran beton segar. Hal ini ditunjukan dengan campuran yang memiliki modulus kehalusan yang sama maka kelecakan campuran beton tersebut relatif sama, sedangkan untuk campuran dengan modulus kehalusan yang semakin tinggi maka kelecakan campuran beton akan turun, kelecakan beton tersebut diukur dengan nilai slumpflow dan waktu V-funne/ seperti yang ditujukan oleh Gambar 3 dan Gambar 4.

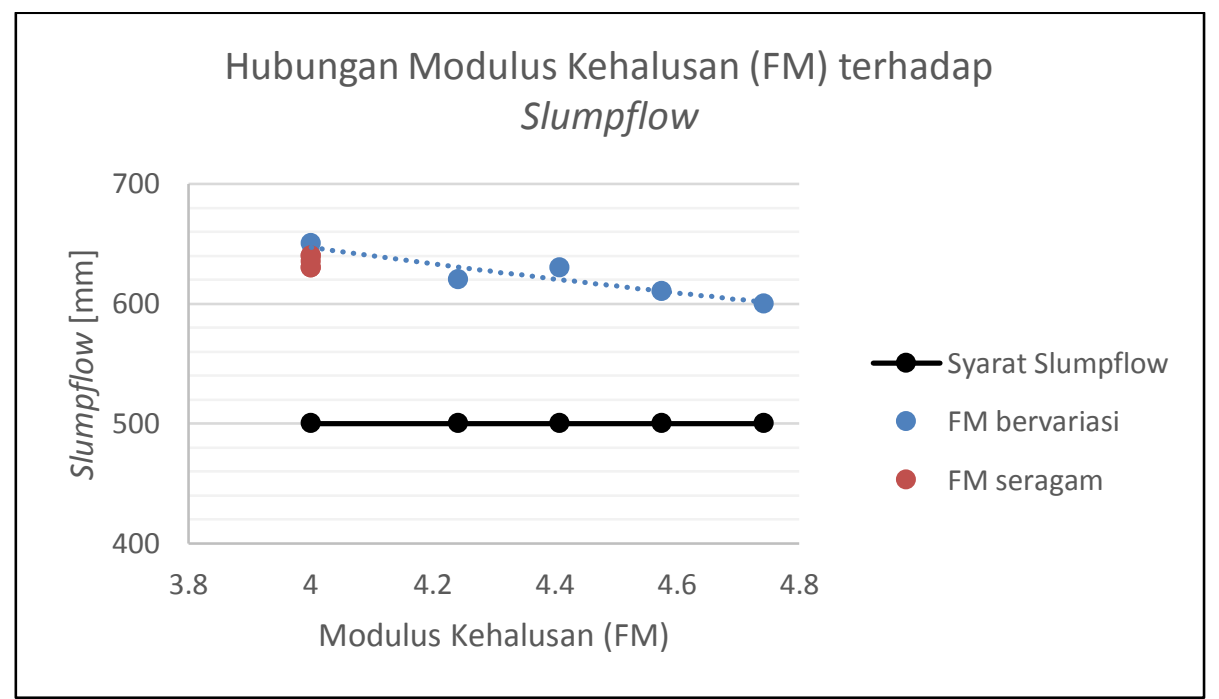

Gambar 3. Grafik pengaruhs/umpflow terhadap modulus kehalusan (FM) kuat tekan 27,38 MPa

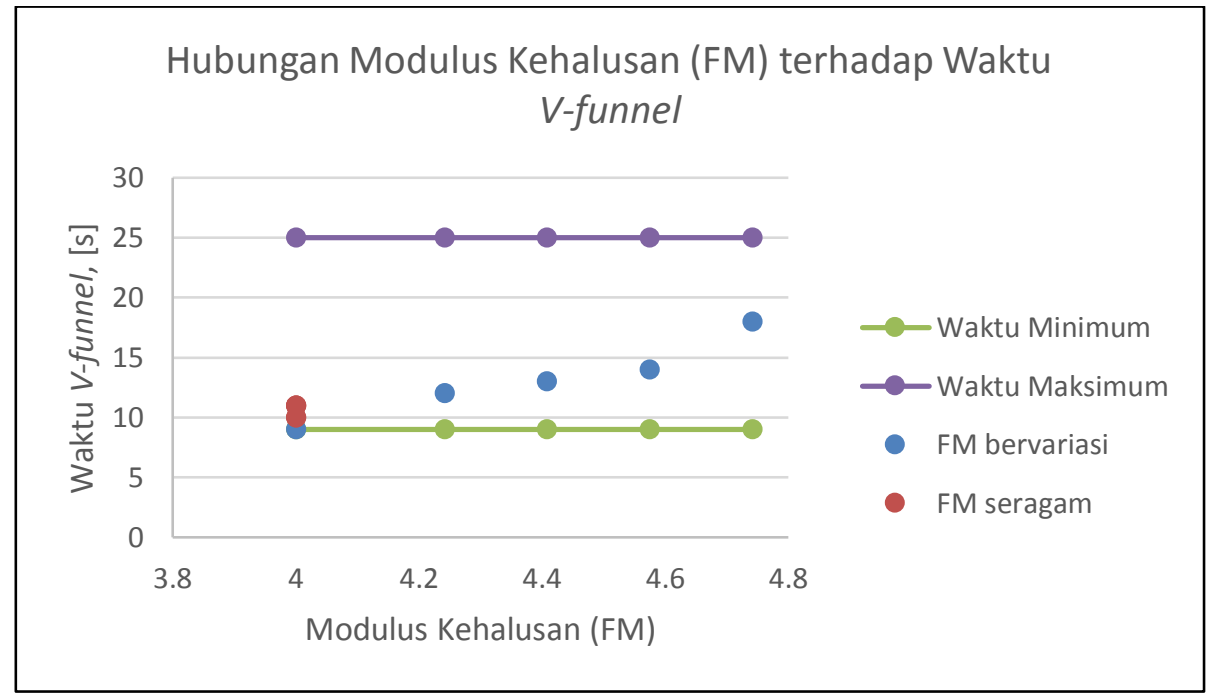

Gambar 4. Grafik pengaruhs/umpflow terhadap modulus kehalusan (FM) kuat tekan 27,38 MPa

RekaRacana: Jurnal Teknik Sipil - 69 
Selanjutnya berikut ini merupakan hasil pengujian beton SCC untuk beton mutu tinggi atau 47,38 MPa dengan modulus kehalusan agregat gabungan seragam dan bervariasi, seperti yang disajikan pada Tabel 12 dan Tabel 13.

Tabel 12. Hasil Pengujian Beton SCC Kuat Tekan 47,38 MPa Modulus Kehalusan Seragam

\begin{tabular}{lccccc}
\multicolumn{1}{c}{ Uraian } & FM1 & FM2 & FM3 & FM4 & FM5 \\
\hline Modulus Kehalusan Gabungan & 4,00 & 4,00 & 4,00 & 4,00 & 4,00 \\
\hline Slumpflow [mm] & 620 & 630 & 620 & 620 & 630 \\
\hline $\boldsymbol{T}_{\text {500, [sec] }}$ & 4 & 4 & 5 & 5 & 4 \\
\hline V-funnel [sec] & 13 & 12 & 12 & 13 & 13 \\
\hline L Box [H2/H1] & 0,45 & 0,42 & 0,42 & 0,47 & 0,40 \\
\hline Kuat tekan 7 hari [MPa] & 32,5 & 32,3 & 31,6 & 30,6 & 29,3 \\
\hline Kuat tekan 28 hari [MPa] & 48,1 & 48,1 & 47,8 & 47,1 & 45,8 \\
\hline
\end{tabular}

Tabel 13. Hasil Pengujian Beton SCC Kuat Tekan 47,38 MPaModulus Kehalusan Bervariasi

\begin{tabular}{lccccc}
\multicolumn{1}{c}{ Uraian } & TM1 & TM2 & TM3 & TM4 & TM5 \\
\hline Modulus Kehalusan Gabungan & 4,00 & 4,24 & 4,40 & 4,57 & 4,74 \\
\hline Slumpflow $[\mathbf{m m}$ ] & 600 & 640 & 630 & 630 & 610 \\
\hline $\boldsymbol{T}_{\mathbf{5 0 0}}$ [sec] & 5 & 6 & 5 & 5 & 6 \\
\hline V-funnel [sec] & 10 & 13 & 15 & 17 & 20 \\
\hline L Box [H2/H1] & 0,55 & 0,38 & 0,36 & 0,35 & 0,31 \\
\hline Kuat tekan 7 hari [MPa] & 31,1 & 32,14 & 31,16 & 32,1 & 32,7 \\
\hline Kuat tekan 28 hari [MPa] & 48,6 & 48,7 & 48,5 & 48,1 & 48,6 \\
\hline
\end{tabular}

Dari hasil pengujian untuk beton SCC dengan mutu tinggi, diperoleh jika campuran beton SCC juga masih dipengaruhi oleh modulus kehalusan agregat gabungan. Hal ini ditunjukan kembali dengan nilai slumpflow dan waktu $V$-funnel, seperti yang ditunjukan oleh Gambar 4 dan Gambar 5. Pada campuran TM 1 untuk ukuran maksimum agregat kasar $10 \mathrm{~mm}$, slumpflow beton segar mempunyai nilai yang rendah, karena pengujian yang dilakukan pertama kali adalah L-box selanjutnya s/umflow. Tetapi nilai $L$-box pada campuran tersebut hampir memenuhi kriteria beton SCC.

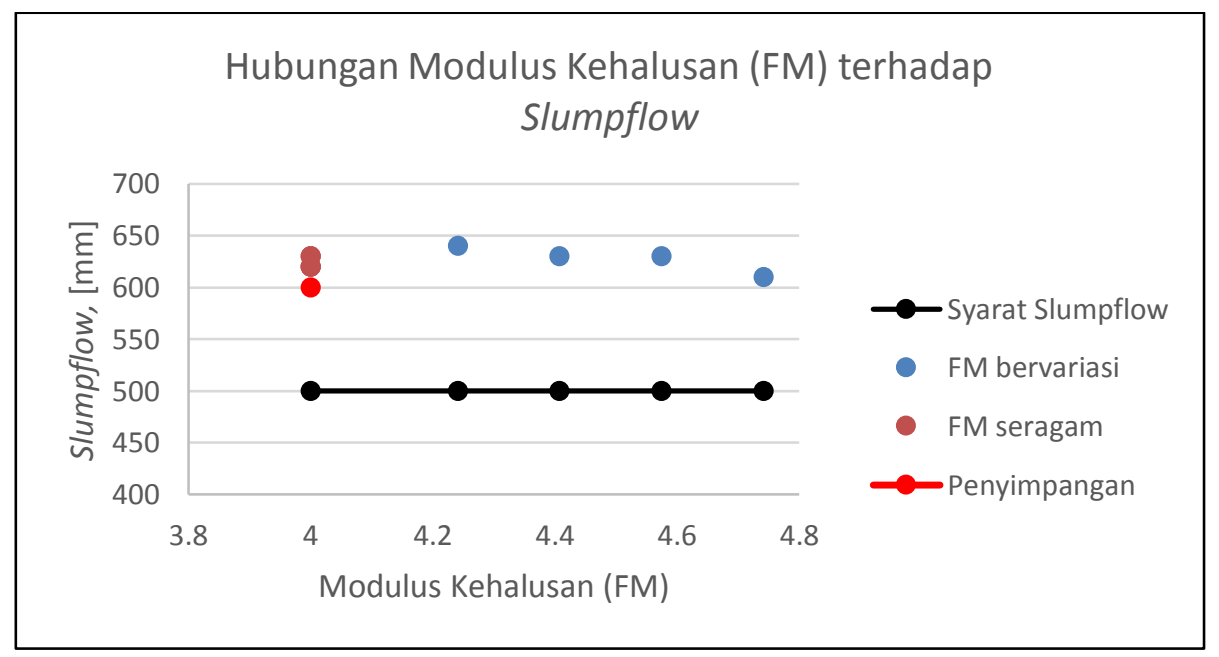

Gambar 5. Grafik pengaruhs/umpflow terhadap modulus kehalusan (FM) kuat tekan 47,38 MPa 


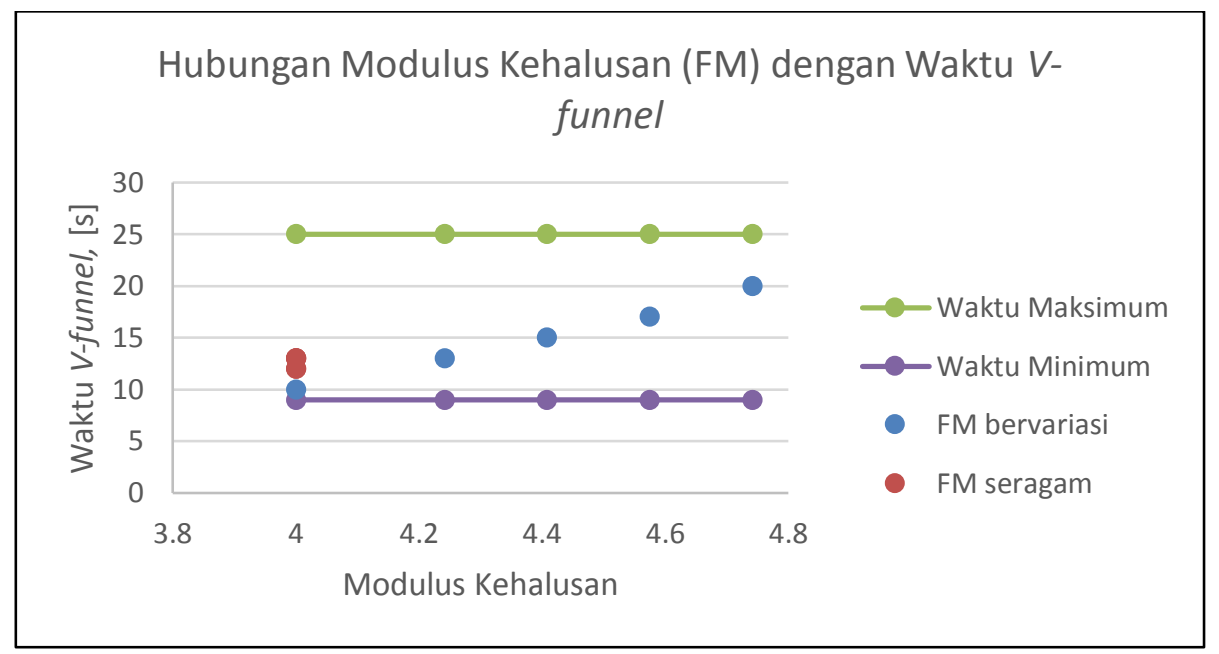

Gambar 6. Grafik pengaruhs/umpflow terhadap modulus kehalusan (FM) kuat tekan 47,38 MPa

Pengujian L-box untuk penelitian ini tidak memenuhi kriteria SCC baik untuk kuat tekan 27,38 MPa dan 47,38 MPa. Hal ini dapat dilihat pada Gambar 7 dan Gambar 8.

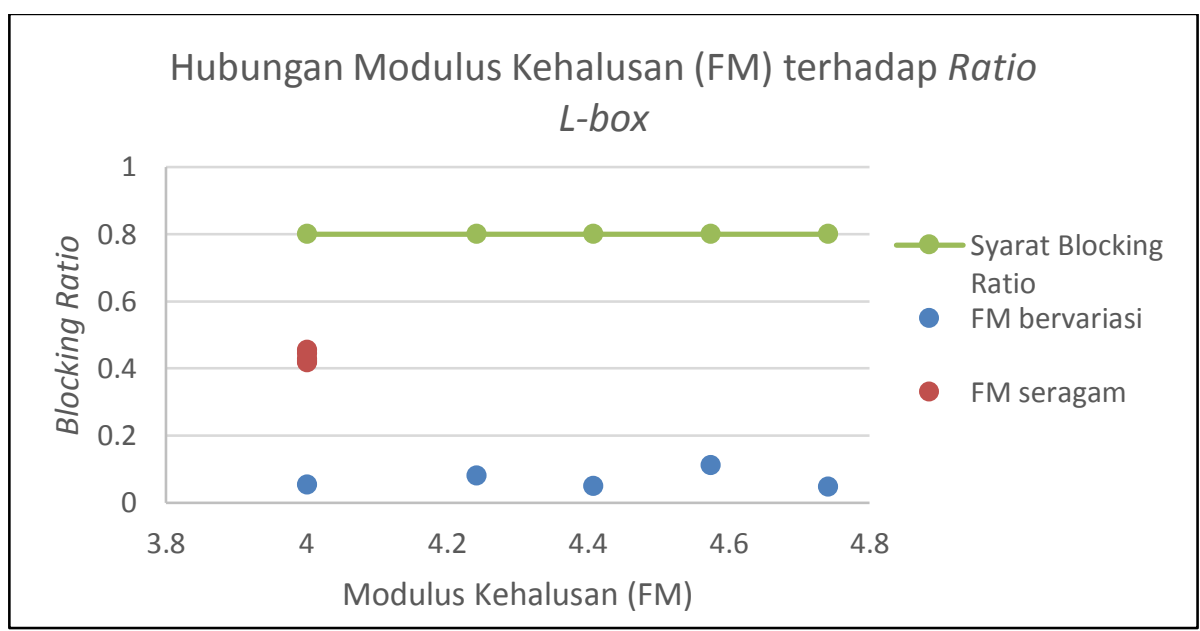

Gambar 7. Grafik pengaruh blocking ratio terhadap modulus kehalusan (FM) kuat tekan 27,38 MPa

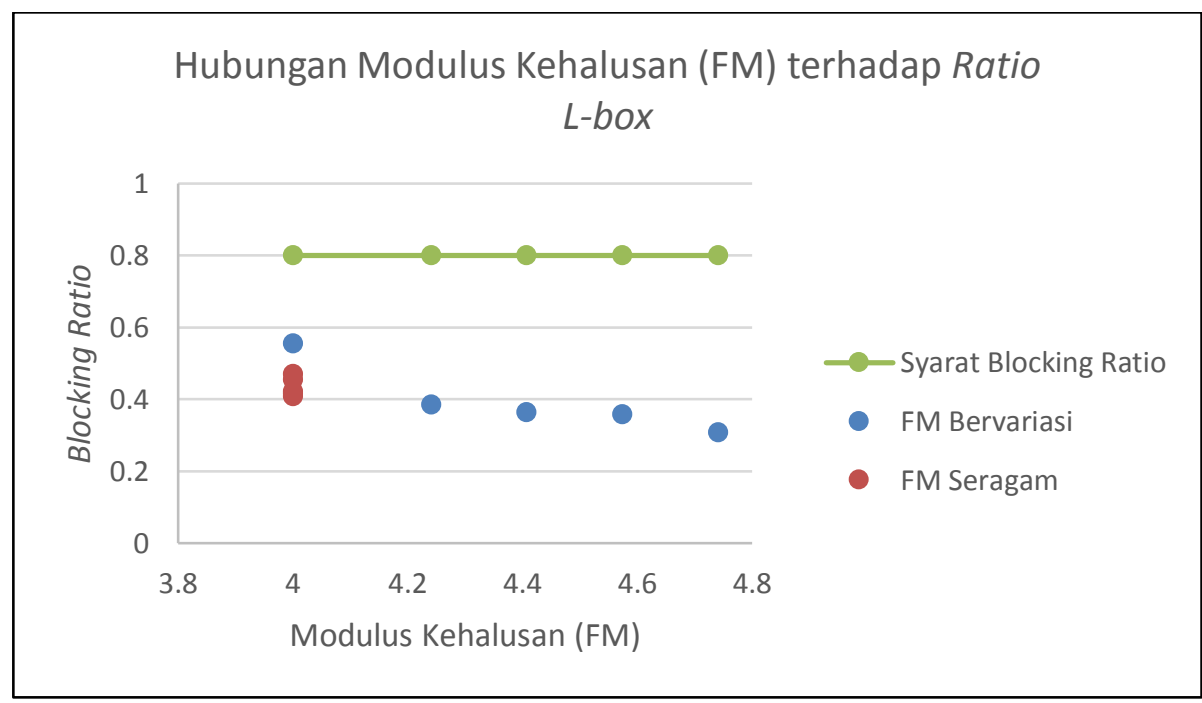

Gambar 8. Grafik pengaruh blocking ratio terhadap modulus kehalusan (FM) kuat tekan 47,38 MPa 
Blocking ratio yang tidak memenuhi kriteria SCC dikarenakan banyaknya beton sisa pada dinding L-box, setting time yang singkat, dan kurangnya kadar superplasticizer. Tetapi jika dilihat dari pengaruh modulus kehalusan, modulus kehalusan yang memiliki nilai yang sama blocking ratio untuk campuran tersebut juga mempunyai nilai yang relatif sama kembali.

Kinerja beton SCC yang dipengaruhi modulus kehalusan ini disebabkan pada modulus kehalusan dengan nilai kecil tetapi ukuran maksimum agregat kasar besar, kelecakan tetap tinggi hal ini dikarenakan ukuran rata-rata butirannya pada campuran tersebut kecil sehingga kelecakannya tinggi. Tapi jika modulus kehalusan memiliki nilai yang tinggi maka ukuran rata-rata agregat pada campurannya besar, sehingga kelecakan campuran beton SCC akan menurun.

Kemudian untuk kuat tekan pada penelitian beton SCC, nilai kuat tekan aktual hasil perancangan mencapai target kuat tekan yang direncanakan baik untuk 7 hari ataupun 28 hari. Hasil uji tekan memenuhi target untuk modulus kehalusan yang bervariasi maupun seragam. Hal ini dapat dilihat pada Gambar 9 dan Gambar 10 untuk kuat tekan target 27,38 MPa dan 47,38 MPa. Sehingga dapat disimpulkan bahwa ukuran maksimum agregat kasar untuk campuran beton memadat sendiri (SCC) tidak mempengaruhi kinerja beton selama campuran memiliki modulus kehalusan yang sama.

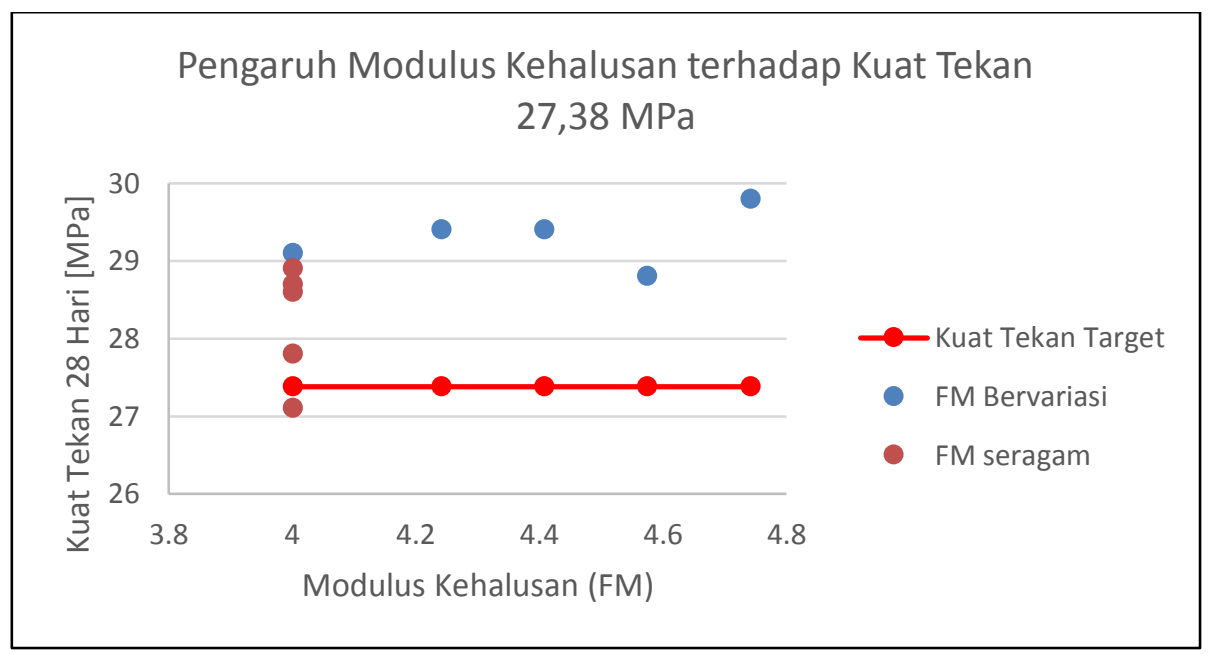

Gambar 9. Grafik pengaruh kuat tekan beton SCC 27,38 MPa terhadap modulus kehalusan (FM)

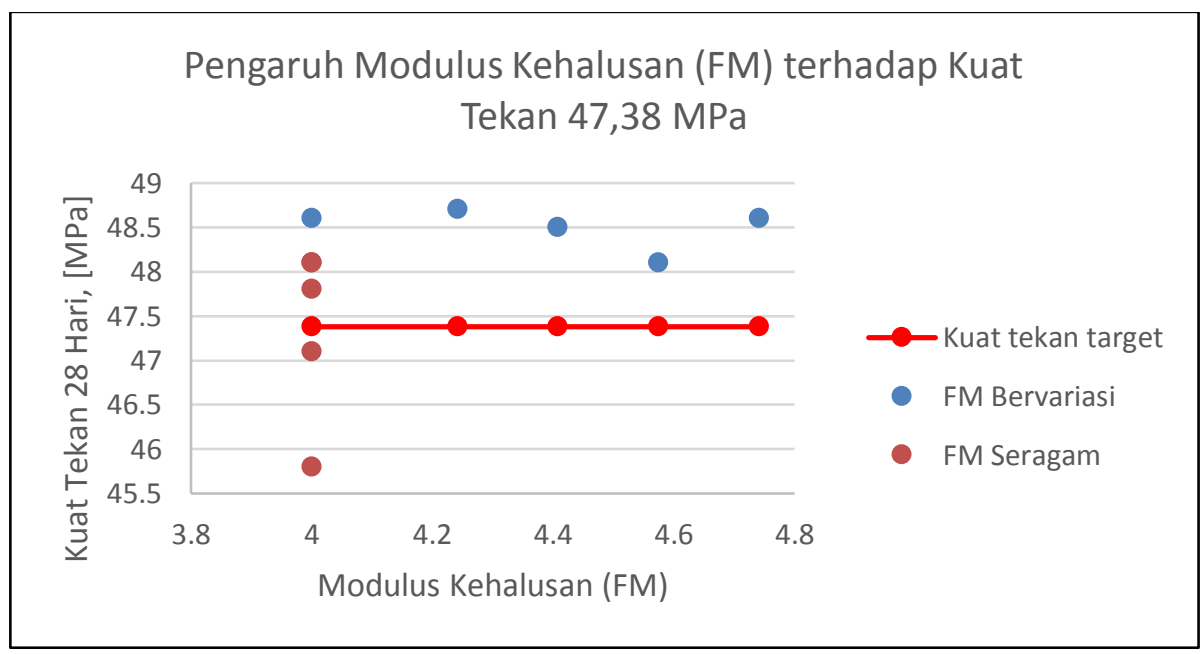

Gambar 9. Grafik pengaruh kuat tekan beton SCC 47,38 MPa terhadap modulus kehalusan (FM) 


\section{KESIMPULAN}

Dari hasil pengujian ukuran maksimum agregat kasar untuk campuran beton SCC ini diperoleh jika ukuran maksimum agregat kasar tidak mempengaruhi kinerja $T_{500}$ beton SCC selama modulus kehalusan gabungan pada campurannya berada pada posisi saringan yang sama pada analisis saringan, ukuran maksimum agregat dan modulus kehalusan gabungan tidak mempengaruhi kuat tekan beton, dan campuran beton SCC mempunyai setting time yang singkat.

\section{SARAN}

Campuran beton SCC dibuat berdasarkan tiap pengujian untuk setiap campurannya karena waktu setting time yang cepat sehingga campuran akan cepat mengental, penambahan retarder pada campurannya untuk memperlambat setting time dan dilakukan perawatan dan kalibrasi pada setiap alat uji untuk mendapatkan hasil pengujian yang lebih akurat.

\section{DAFTAR RUJUKAN}

EFNARC. (2005). The European Guidelines for Self-Compacting Concrete. European Project Group.

Abdelgader dan rekan. (2014). Mix design of self-compacting concrete using local material " A case study from Libya".

Saelan, P. Ir., M.T. dan Zaenal Arifin. (2002). Kaji banding perencanaan gradasi bercelah dalam campuran beton dengan menggunakan cara modulus kehalusan dan permukaan spesifik. 